\title{
Biodegradable Films Made from Raw and Acetylated Cassava Starch
}

\author{
Fábio D. S. Larotonda ${ }^{1}$, Kátia N. Matsui ${ }^{1}$, Valdir Soldi ${ }^{2}$ and João B. Laurindo ${ }^{1 *}$ \\ ${ }^{I}$ Laboratório de Propriedades Físicas de Alimentos - PROFI; Departamento de Engenharia Química e Engenharia \\ de Alimentos; Universidade Federal de Santa Catarina; C. P. 476; 88040-900; Florianópolis - SC - Brazil. ${ }^{2}$ Grupo \\ de Estudo em Materiais Poliméricos - POLIMAT; Departamento de Química; Universidade Federal de Santa \\ Catarina; C. P. 476; 88040-900; Florianópolis - SC - Brazil
}

\begin{abstract}
Studies were carried out to produce biodegradable films from cassava starch. Two alternatives were investigated. In the first, films were obtained by starch gelatinization followed by thermopressing and glycerol was used at different concentrations as a plasticizer. In the second, starch acetate films were obtained by solubilization of cassava starch acetate in organic solvents, followed by casting on a glass plate and drying at room temperature. The films obtained by gelatinization were transparent and resistant to traction. The starch acetate films were also transparent but breakable. The use of these starch acetate films in paper impregnation improved the mechanical properties of the paper.
\end{abstract}

Keywords: Cassava, starch acetate, films, tensile strength

\section{INTRODUCTION}

Throughout its history, mankind has explored the earth's natural resources without limits, extracting raw materials for industry. The capacity of the planet to absorb and to transform the wastes that resulted from modern life seemed to be inexhaustible. With the exponential increase in the planet population, the situation has become a matter of great concern (Akovali et al., 1998). The population and economic growth in the majority of the western countries has resulted in an enormous increase in waste production. Statistical data show that in Brazil, about 240 to 300 thousand tons of urban solid residues are discharged daily into the environment, of which about $19 \%$ are plastics derived from oil. The annual plastic production is approximately 2.2 million tons, of which $40 \%$ is destined for the packing industry. To solve these problems, alternatives are being studied, such as the recycling of plastic products and the substitution of conventional plastics for biodegradable ones (Sotero, 2000).

The success of synthetic plastic can be explained by the low cost, easy processing, high applicability and durability. However, it cannot be degraded in the environment by microorganisms in the long term (Feil, 1995). This problem was recognized back in and ways to recycle these materials by means of initiatives that match practicability and economy are being investigated. It must be considered too, that it is desirable that the decomposition processes of these materials result in inert or biodegradable by-products (Shogren et al., 1993). The interest in the use of renewable raw materials in industrial processes is a natural

\footnotetext{
* Author for correspondence
} 
consequence of this panorama and is intensifying (Doane et al., 1992).

Although most of the recent research has been focused on the conversion of starch into thermoplastic material by the extrusion process, other means of preparing films, e.g. from solution or gel, have also been used (Lourdin et al., 1995; Bader and Göritz, 1994) as an attractive alternative (Rindlav et al., 1997). Starch is an inexpensive and abundant product available in nature. It is totally biodegradable in a wide variety of environments and can used in the development of totally degradable products for specific market needs. Degradation or incineration of starch products recycles the atmospheric $\mathrm{CO}_{2}$ trapped by starchproducing plants during their growth, thus closing the biological carbon cycle (Bastioli, 1998). Starch is constituted by two major components: amylose, a mostly linear alpha-D-(14)-glucan and amylopectin, an alpha-D-(1-4) glucan which has alpha-D-(1-6) linkages at the branch point. The linear amylose molecules of starch have a molecular weight of 0.2-2 million, while the branched amylopectin molecules have molecular weights as high as 100-400 million (Buléon et al., 1998).

Cereda et al. $(1992,1995)$ showed that the use of cassava starch films was promising, giving a good appearance, without stickiness, exhibiting shininess and transparency. Vicentini et al. (1999) developed edible coatings derived from cassava starch to minimize postharvest losses. Cereda et al. (2000) characterized coatings of both natural and modified cassava starch using scanning electron microscopy as a method of learning more about their structures when applied to surface of fruits, vegetables and flowers. Andrade et al. (2000) developed a new type of composite material, constituted of thermoplastic starch reinforced with chitin. Vicentini et al. (2001) also developed edible films based on a mixture of cassava starch and wheat gluten. Rosa et al. (2001) reported a methodology for preparing new polymer blends, containing different quantities of starch, with poly(e-caprolactone), poly( $\beta$-hydroxybutyrate) and poly ( $\beta$-hydroxybutyrate-co-b-hydroxyvalerate). Mali et al. (2002) developed biodegradable and edible yam starch films. These studies and the references therein report a renewed interest in the research of materials based on starch.

Among the agricultural crops that produce starch, one of the most utilized in Brazil is cassava, and
Brazil is the second worldwide producer of this root, after Nigeria (FAO, 2001).

The use of cassava would not only create an economic alternative for Brazilian cassava agriculture but would also lead to a reduction in the impacts caused by the intense use of packaging derived from oil (polyethylene, polystyrene, etc). In this study, we used cassava starch to made films through the chemical modification of cassava starch by acetylation reaction (esterification) and by gelatinization of the cassava starch in aqueous solution.

\section{MATERIALS AND METHODS}

\section{Cassava Starch Acetate (CSA) films}

The synthesis of CSA was partially based on Feuer (1998). The synthesized CSAs were evaluated in relation to their degree of substitution (DS) (or degree of acetylation). A sample of the polymer was hydrated by boiling in $50 \mathrm{~mL}$ of an alcoholic solution $(75 \% \mathrm{v} / \mathrm{v})$ and the polymer was saponified with $40 \mathrm{~mL}$ of a $0.5 \mathrm{~N}$ sodium hydroxide $(\mathrm{NaOH})$ solution, the excess of $\mathrm{NaOH}$ was then back titrated with hydrochloric acid $(\mathrm{HCl}) \quad 0.5 \mathrm{~N}$ (Wurzburg, 1964). Infrared spectra were recorded using a Perkin Elmer FT16PC apparatus. Starch and CSA Spectra were obtained in of $\mathrm{KBr}$ pellets. The CSA films were obtained using the casting technique. The solvents tested for the preparation of the filmogenic solution were: acetone (P.A.), chloroform (P.A.) and tetrahydrofuran (THF). The solution was prepared dissolving CSA in one of the solvents in the ratio of 1:5. The CSA used to produce the films was synthesized at $80^{\circ} \mathrm{C}$ and the degree of substitution (DS) was 1.50. After the solution was prepared, it was dispersed on a $10 \mathrm{~cm}$ diameter glass Petri dishes. The thickness of the film was controlled in accordance with the height of the filmogenic solution on the glass Petri dishes and was about $0.400 \mathrm{~mm}$.

\section{Gelatinized CS films}

A starch:water:glycerol mixture was prepared, varying the glycerol concentration (10:200:0; $10: 200: 0.5 ; 10: 200: 1 ; 10: 200: 1.5 ; 10: 200: 2)$. The mixtures were submitted to heating to $55^{\circ} \mathrm{C}$ while stirring. The mixture was transferred to a Teflon ${ }^{\circledR}$ plate with a aluminum guide and thermopressed in a hydraulic press machine with a control system for temperature and pressure. The thermopressing was carried out at $80^{\circ} \mathrm{C}$ and $1 \mathrm{MPa}$ pressure was 
applied for 5 minutes. The aluminum guide on the Teflon $^{\circledR}$ plate was then removed and another thermopressing was carried out at $80^{\circ} \mathrm{C}$ for 5 minutes, applying a pressure of approximately 1 MPa to define the thickness of the film. The film formed on the Teflon ${ }^{\circledR}$ plate was dried at $25^{\circ} \mathrm{C}$ for $8 \mathrm{~h}$. Films were stored for 7 days at $25^{\circ} \mathrm{C}$ and a relative humidity of $75 \%$ in a desiccator with a saturated solution of sodium chloride $(\mathrm{NaCl})$.

An analysis by differential scanning calorimetry (DSC) was carried out to verify the interval of the gelatinization temperature for cassava starch, using a Differential Scanning Calorimeter, model DSC50, SHIMADZU; with aluminum pans under a nitrogen atmosphere. One empty pan was used as a reference. A dispersion of CS was prepared with $200 \mathrm{mg}$ of CS in $1 \mathrm{~mL}$ of distilled water. The sample was analyzed from room temperature $( \pm$ $25^{\circ} \mathrm{C}$ ) up to $100^{\circ} \mathrm{C}$, scanning with a heating rate of $5^{\circ} \mathrm{C}$ per minute.

\section{Mechanical tests}

To determine the resistance of the films to the traction, mechanical tests were carried out in accordance with the standard ASTM-D-882-9a in a Universal Testing Machine, model DL2000, EMIC, using the load cell R2797 (500 N). For the traction tests with CSA, the samples were prepared dissolving CSA in chloroform in a ratio of 1:5 and impregnating samples of paper. The dimensions of the samples (impregnated paper with CSA and gelatinized CS films) were $2.5 \times 10.0 \mathrm{~cm}$. The thickness of the gelatinized CS films and of the impregnated samples were determined using a digital manual micrometer (Mitutoyo Co., Japan) at 4 positions on the samples. The average thickness of the CS films was $0.101 \mathrm{~mm}$. The average thickness of the impregnated and nonimpregnated samples was used to determine the thickness of the CSA film. The difference between these two thicknesses was the CSA film thickness formed on the paper. The average thicknesses of non-impregnated paper, impregnated paper and CSA films were $0.105,0.130$ and $0.025 \mathrm{~mm}$, respectively. Traction tests were also carried out for the paper samples without impregnation with the CSA solution, to verify the influence of the CSA on the resistance to traction. The traction tests for the gelatinized starch films were carried out on samples with the same dimensions given above.

\section{RESULTS AND DISCUSSION}

\section{Cassava starch acetate}

The CSA obtained in the acetylation reactions, was a white powder and was soluble in organic solvents such as acetone, chloroform and tetrahydrofuran (THF). Feuer (1998) also described similar characteristics for CSA. It was observed that the reaction mixture, initially a not very viscous white solution, became an amber solution, translucent and viscous. At the end of the reaction, when frozen water was added, white particle precipitation occurred.

Fig. 1 shows the influence of the reaction temperature on the degree of substitution obtained in the starch acetylation reactions during the synthesis of CSA. It was observed that the degree of substitution of CSA improved with the increase in the reaction temperature. Feuer (1998) and Lepeniotis and Feuer (1997) achieved the same results in their experiments.

The infrared spectra of CS and CSA are given in Fig. 2. These spectra were characterized by the presence of four important absorption bands: $\mathrm{OH}$ and $\mathrm{C}=\mathrm{O}$ stretching at 3500 and $1750 \mathrm{~cm}^{-1}$, respectively; $\mathrm{C}-\mathrm{CH}_{3}$ deformation at $1375 \mathrm{~cm}^{-1}$, and a C-O stretching at $1240 \mathrm{~cm}^{-1}$.. It could be observed, when the spectra of CS and CSA were compared, that the acetylation really occurred at $3500 \mathrm{~cm}^{-1}$ and at $1750 \mathrm{~cm}^{-1}$. In the acetylation reaction a substitution of the $\mathrm{OH}$ groups in the starch occurred, that could be seen in the decrease in the intensity of the band at $3500 \mathrm{~cm}^{-1}$ and the increase the intensity of the band at $1750 \mathrm{~cm}^{-1}$.

Procedures aiming to obtain CSA films were carried out using the casting technique, forming transparent, but very fragile, films. Figs. 3(a), 3(b) and 3(c) show photographs of the CSA films, prepared by the casting technique, using respectively, acetone, chloroform and tetrahydrofuran (THF) as solvents. In all three cases, the drying process promoted film shrinkage, which could be explained by the solvent evaporation and air inclusion.

This process leads to the film structure collapse, as explained by Eichler et al. (1997). The films obtained using acetone and chloroform as solvents were very similar and very transparent. The use of THF as the solvent produced less transparent and less breakable films. 


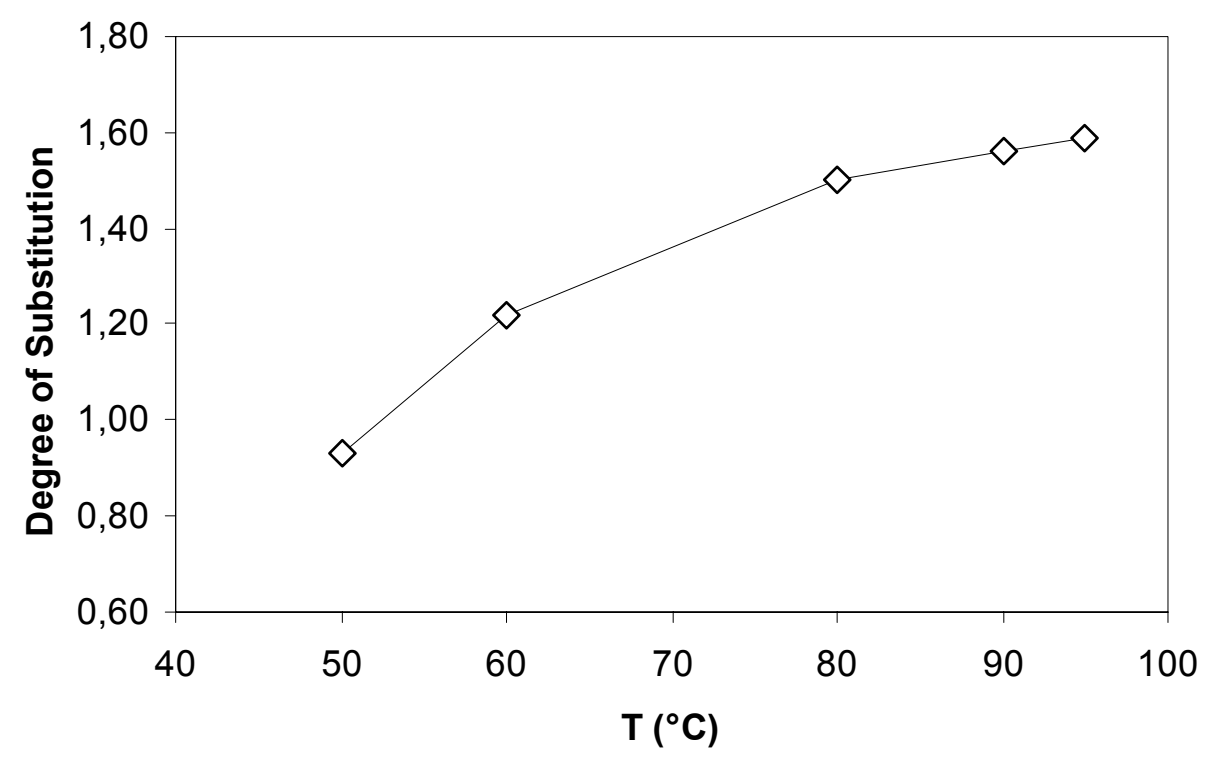

Figure 1 - Temperature influence on the degree of substitution (DS).

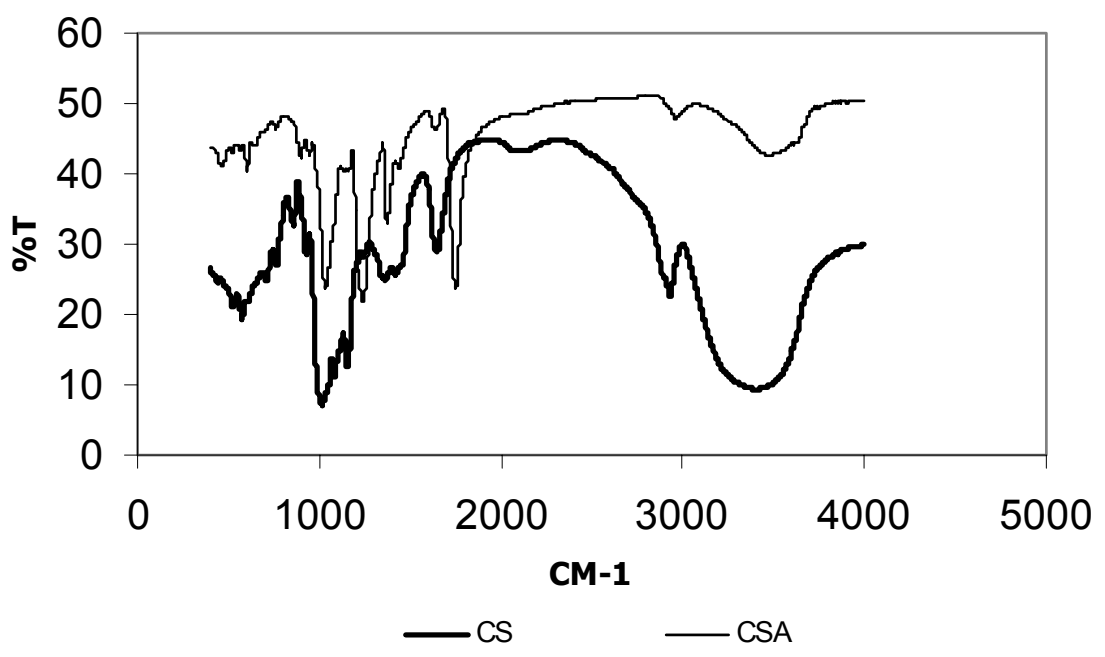

Figure 2 - Infrared spectra of CS and CSA. 


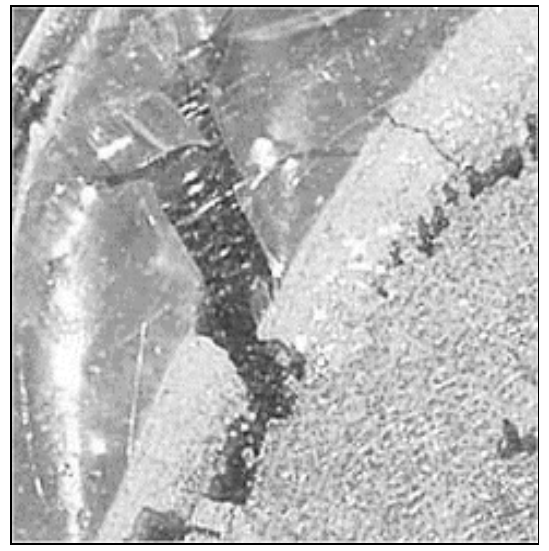

(a)

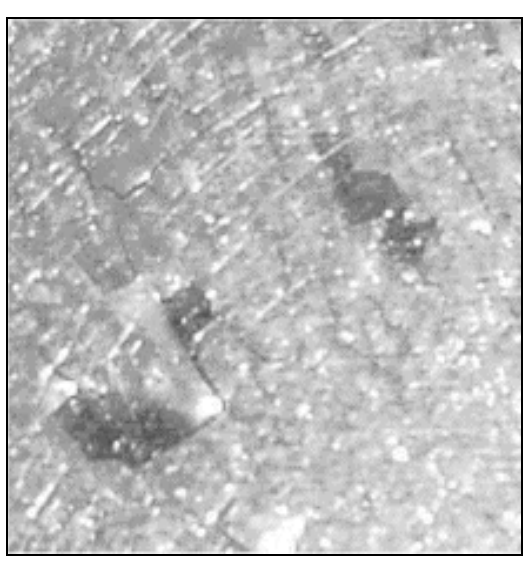

(b)

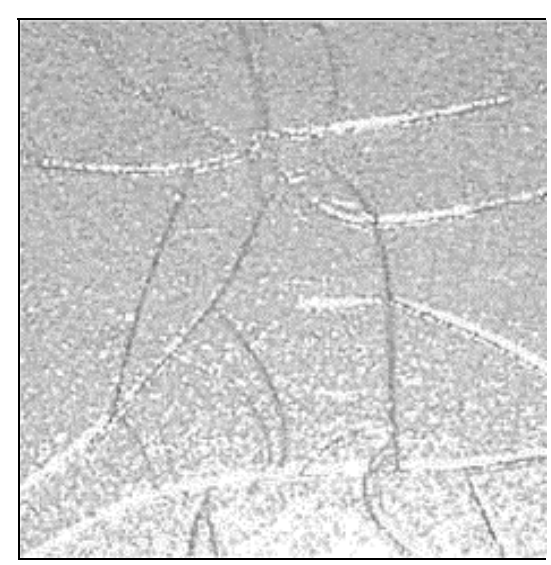

(c)

Figure 3 - CSA films prepared by casting using as solvent: (a) acetone, (b) chloroform, (c) tetrahydrofuran (THF).

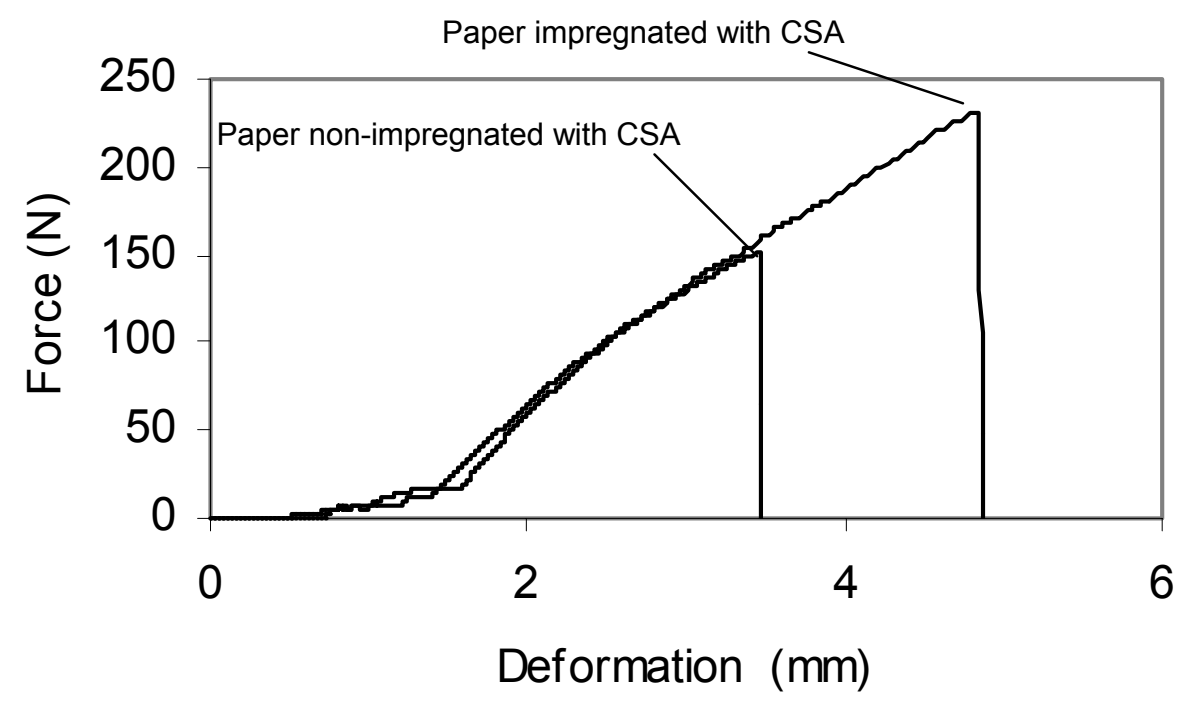

Figure 4 - Effect of the impregnation of the paper with CSA on the tensile strength properties.

\section{Gelatinized CS films}

The gelatinized CS films obtained by thermopressing were transparent and resistant to traction. However, they showed low resistance to tearing and to direct humidity. The addition of glycerol to the dispersion made the films more malleable, as expected, because glycerol was used as a plasticizer. The film malleability increased according to the increase in the amount of glycerol added.
A thermogram was obtained for the verification of the gelatinization temperature interval of the utilized CS. The gelatinization temperature obtained was in the range of $55.12^{\circ} \mathrm{C}$ (beginning of the transition) to $74.17^{\circ} \mathrm{C}$ (end of the transition), with a peak at $64.96^{\circ} \mathrm{C}$. Bobbio and Bobbio (1995) reported that the temperature interval of gelatinization for the $\mathrm{CS}$ was between $58^{\circ} \mathrm{C}$ and $70^{\circ} \mathrm{C}$. 


\section{Mechanical tests}

The results of the traction tests are shown in Fig. 4. It was observed that the samples impregnated with the CSA solution supported breaking strengths about 1.5 times higher than the nonimpregnated samples. This might be due to the interactions that occurred between CSA and the impregnated paper, with the paper pores filled with the CSA, thus magnifying its resistance to tensile strength.

Fig. 5 shows the effect of the plasticizer concentration of the mixture (starch-waterplasticizer) on the tensile strength results. Fig. 5 also shows that the sample containing $0 \%$ glycerol presented a tension value at rupture of $316.3 \mathrm{MPa}$ and $3.68 \%$ elongation. Increasing the amount of glycerol in the mixture, the tension values and elongation at rupture decreased, except for 5\% glycerol, where the elongation at rupture had a value of $3.83 \%$. For the sample with $20 \%$ glycerol, the tension value at rupture decreased by around $50 \%$ and the elongation value at rupture decreased by around $60 \%$. Morais et al. (2001) results agree with the results obtained in this study, i.e, there was a simultaneous decrease in tensile strength and elongation with low glycerol contents. Lourdin et al. (1997) and Gaudin et al. (1999) reported the antiplasticiser effect of glycerol and sorbitol under the above conditions. For Gaudin et al. (2000), the cause of this behavior has not been clearly elucidated, but it would appear that local molecular mobilities play a important role in the mechanisms involved. Myllärinen et al. (2002) reported the same phenomenon for glycerol antiplasticization when it was used to plasticize amylose and amylopectin films. With low glycerol contents both tensile strain and elongation decreased, but above 20\% glycerol, elongation reached larger values.

Fig. 6 shows the relation between the force (tension) applied to the sample and the deformation suffered by it. It was observed that the samples containing 0,5 and $10 \%$ glycerol supported the highest tensions, and samples with 0 and $5 \%$ of glycerol suffered the highest deformations.

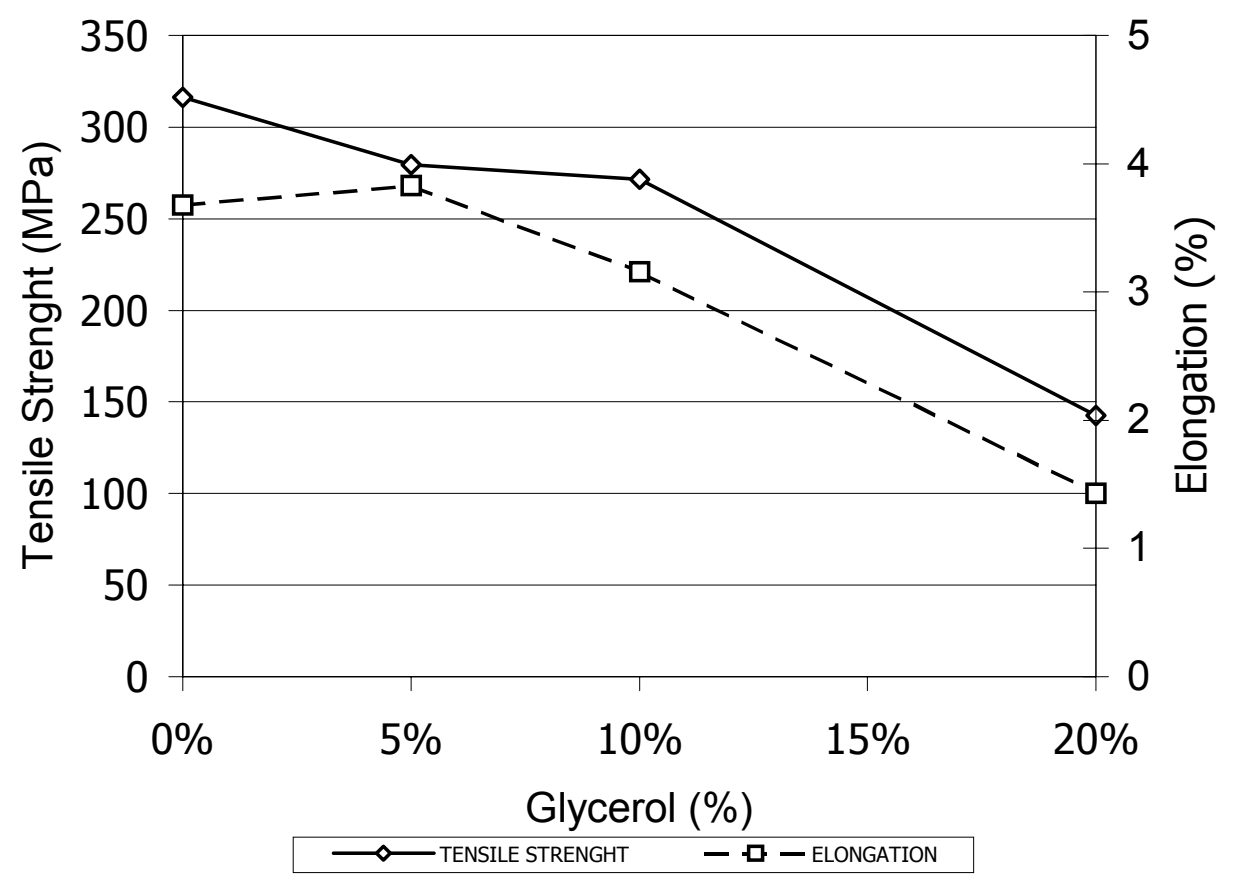

Figure 5 - Effect of plasticizer (glycerol) concentration of the starch-water-plasticizer mixture $(10: 200: 0 ; 10: 200: 0.5 ; 10: 200: 1 ; 10: 200: 1.5 ; 10: 200: 2)$ on the results of traction tests. Values refer to the rupture point of the samples. 


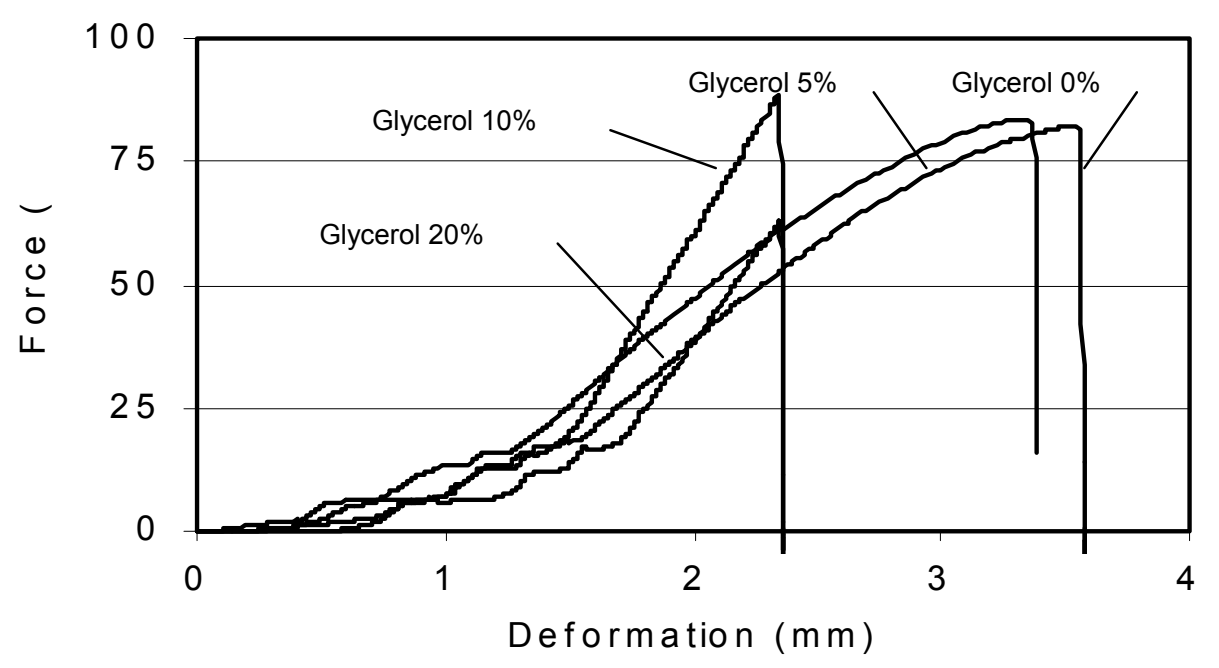

Figure 6 - Applied force x Deformation for the starch films with different percentages of glycerol.

\section{CONCLUSIONS}

\section{Cassava Starch Acetate (CSA) films}

Based on these results, it could be concluded that the synthesis temperature of the starch acetate should be in the range of $60-90^{\circ} \mathrm{C}$ to obtain degrees of substitution in the range of 1.22 and 1.56. The films obtained by the casting technique were transparent and very fragile. On the other hand, the impregnation of paper with CSA revealed an interesting alternative for its use.

\section{Gelatinized CS films}

The gelatinized CS films showed good transparency and tensile strength. It was demonstrated that the addition of glycerol as a plasticizer agent did not improve the mechanical properties of the films. However, with reference to malleability, the addition of glycerol improved the film characteristics.

\section{ACKNOWLEDGEMENTS}

The authors gratefully acknowledge CAPES and $\mathrm{CNPq}$ for financial support.

\section{RESUMO}

A reciclagem de produtos constituídos por polímeros sintéticos e sua substituição por materiais biodegradáveis estão sendo estudadas como alternativas para reduzir a poluição ambiental causada por estes materiais. Neste contexto, o amido está recebendo considerável atenção entre os recursos renováveis que podem ser usados para a fabricação de materiais para embalagem. O objetivo deste trabalho foi produzir filmes biodegradáveis a partir do amido da mandioca. Duas alternativas foram investigadas. Na primeira, os filmes foram obtidos pela gelatinização do amido seguida de termoprensagem, utilizando o glicerol em concentrações diferentes como o plastificante. A outra alternativa estudada foi a acetilação do amido de mandioca. Os filmes de acetato de amido foram obtidos pela solubilização do acetato em solventes orgânicos, seguido do espalhamento da solução em uma placa de vidro e secagem em temperatura ambiente. Os filmes obtidos pela gelatinização do amido mostraram-se transparentes e resistentes à tração. Os filmes de acetato de amido mostraram-se transparentes e quebradiços. No entanto, seu uso para a impregnação de papel melhorou as propriedades mecânicas deste último.

\section{REFERENCES}

Akovali, G.; Bernardo, C. A.; Leidner, J.; Utracki, L. A. and Xanthos, M. (1998), Frontiers in the science and technology of polymer recycling - NATO ASI. Kluwer Academic Publishers. (Series E: Applied Sciences; 351). 
Andrade, C. T.; Souza, R. C. R.; Barbosa, L. C. and Silva, K. M. P. (2000), Use of chitin as reinforcing material in biodegradable thermoplastic starch. In: Natural Polymers and Composites. São Paulo : Embrapa Instrumentação Agropecuária.

Bader, H. G. and Göritz, D. (1994), Investigations on high amylose corn starch films. Part I: Wide-angle Xray scaterring (WAXS). Starch/Stärke, 46, 229-232.

Bastioli, C. (1998), Properties and applications of Mater-Bi starch based materials. Polymer Degradation and Stability, 59, 263-272.

Bobbio, F. O and Bobbio, P. A. (1995), Introdução à química dos alimentos. 2. ed. São Paulo : Varela.

Buléon, A.; Colonna, P.; Planchot, V. and Ball, S. (1998), Starch granules: structure and biosynthesis. International Journal of Biological Macromolecules, 23, 85-112.

Cereda, M. P.; Bertolini, A. C. and Evangelista, R. M. (1992), Uso do amido em substituição às ceras na elaboração de filmes na conservação pós-colheita de frutas e hortaliças: estabelecimento de curvas de secagem. In: 7. Congresso Brasileiro de Mandioca. Anais... Recife. pp. 107.

Cereda, M. P.; Bertolini, A. C.; Silva, A. P.; Oliveira, M. A. and Evangelista, R. M. (1995), Películas de almidón para la preservación de frutas. In: Congresso Polimeros Biodegradables: Avances y Perspectivas. Anais... Buenos Aires. pp. 42.

Cereda, M. P.; Henrique, C. M.; Oliveira, M. A.; Ferraz, M. V. and Vicentini, N. V. (2000), Characterization of edible films of cassava starch by electron microscopy. Brazilian Journal of Food Technology, 3, 91-95.

Doane, W. M.; Swanson, C. L. and Fanta, G. F. (1992), Emerging Polymeric Materials Based on Starch, ACS Symposium Series 476 Washington. pp. 197-230.

Eichler,S.; Ramon, O.; Ladyzhinski, I.; Cohen, Y. and Mizrahi, S. (1997). Collapse processes in shrinkage of hidrophilic gels during dehydration. Food Research International, 30, 719-726.

FAO (2001), Food and Agriculture Organization of the United Nations. <http://apps.fao.org/page/collections>.

Feil, H. (1995), Biodegradable plastics from vegetable raw materials. Agro-Food-Industry Hi-Tech, 25-32.

Feuer, B. I. (1998), Method of making starch acetate using an acid catalyst. USA Patent $\mathrm{n}^{\circ}$ 5, 710, 269.

Gaudin, S.; Lourdin, D.; Le Botlan, D.; Ilari, J. L. and Colonna, P. (1999), Plasticisation and mobility in starch-sorbitol films - Journal of Cereal Science, 29, 273-284.

Gaudin, S.; Lourdin, D.; Forssell, P. M. and Colonna, P. (2000), Antiplasticisation and oxygen permeability of starch-sorbitol films. Carbohydrate Polymers, 43, 33-37.

Lepeniotis, S. and Feuer, B. I. (1997), Synthesis of starch acetate: statistical designed experiments to optmize the reaction conditions. Chemometrics and Intelligent Laboratory Systems, 36, 229-243.
Lourdin, D.; Della Valle, G. and Collona, P. (1995), Influence of amylose content on starch films and foams. Carbohydrate Polymers, 27, 261-270.

Lourdin, D.; Bizot, H. and Colonna P. (1997), Antiplasticization in starch-glycerol films? Journal of Applied Polymer Science, 63, 1047-1053.

Mali, S.; Grossmann, M. V. E.; Garcia, M. A; Martino, M. N. and Zaritzky, N. E. (2002), Microstrucural characterization of yam starch films. Carbohydrate Polymers, 50, 379-386.

Morais, L. C.; Carvalho, A. J. F.; Da Róz, A. L. and Curvelo, A. A. S. (2001), Preparação e caracterização de termoplásticos a partir de lignossulfato e amido. In: 6. Congresso Brasileiro de Polímeros / 9. International Macromolecular Colloquium. Anais... Gramado/RS.

Myllärinen, P.; Partanen, R.; Seppälä, J. and Forssell, P. (2002), Effect of glycerol on behaviour of amylose and amylopectin films. Carbohydrate Polymers, 50, 355-361.

Narayan, R.; Bloembergen, S. and Lathia, A. (1999), Method of preparing biodegradable modified-starch moldable products and films. USA Patent $\mathrm{n}^{\circ}$ $5,869,647$.

Rindlav, A.; Hulleman, S. H. D. and Gatenholm, P. (1997), Formation of starch films varying crystallinity. Carbohydrate Polymers, 34, 25-30.

Rosa, D. V.; Franco, B. L. M. and Calil, M. R. (2001), Biodegradabilidade e propriedades mecânicas de novas misturas poliméricas: polímeros. Ciência $e$ Tecnologia, 11 : (2), 82-88.

Shogren, R. L.; Fanta, G. F. and Doane, W. M. (1993), Development of starch based plastics - A reexamination of selected polymer systems in historical perspective. Starch/Stärke, 8, 276.

Sotero, A. P. (2000) Plásticos biodegradáveis trazem melhoria ambiental. Jornal de Plásticos, 1017/1018.

Vicentini, N. M.; Cereda, M. P. and Câmara, F. L. A. (1999), Revestimentos de fécula de mandioca, perda de massa e alteração da cor de frutos de pimentão. Scientia Agrícola, 56 : (3), 713-716.

Vicentini, N. M.; Sobral, P. J. A. and Cereda, M. P. (2001), Desenvolvimento de filmes comestíveis a base de misturas de fécula de mandioca e glúten de trigo. In: 4. Simpósio Latino Americano de Ciência de Alimentos. Resumos... Campinas : FEA/UNICAMP. pp. 183 - 183.

Wurzburg, O. B. (1964), Acetylation. Methods in Carbohydrate Chemistry, 4.

Received: May 15, 2002; Revised: February 25, 2003; Accepted: February 25, 2004. 